\title{
Status of current medicolegal reform in the United States: a neurosurgical perspective
}

\author{
Devon LeFever, MD, ${ }^{1}$ Audrey Demand, MS, ${ }^{1}$ Sandeep Kandregula, MBBS, ${ }^{1}$ Alexis Vega, MS, ${ }^{1}$ \\ Breydon Hobley, ${ }^{1}$ Soleil Paterson, BS, RN, ${ }^{1}$ Krystle Trosclair, PhD, ${ }^{1}$ Richard Menger, MD, MPA, ${ }^{2}$ \\ Jennifer Kosty, MD, ${ }^{1}$ and Bharat Guthikonda, MD, MBA ${ }^{1}$
}

\begin{abstract}
1Department of Neurosurgery, Louisiana State University Health Sciences Center, Shreveport, Louisiana; and 'Department of Neurosurgery Specialists, University of South Alabama, Mobile, Alabama
\end{abstract}

\begin{abstract}
OBJECTIVE There are approximately 85,000 lawsuits filed against medical practitioners every year in the US. Among these lawsuits, neurosurgery has been identified as a "high-risk specialty" with exceptional chance of having medical malpractice suits filed. Major issues affecting the overall medicolegal environment include tort reform, the formation of medical review panels, the increasing practice of defensive medicine, and the rising costs of medical insurance. In this study, the authors provide a concise update of the current medicolegal environments of the 50 states and provide a general guide to favorable and unfavorable states in which to practice neurosurgery.

METHODS Data were acquired related to state-by-state medical review panel status, noneconomic damage caps, economic damage caps, and civil suit filing fees. States were placed into 5 categories based on the status of their current medicolegal environment.
\end{abstract}

RESULTS Of the 50 states in the US, 18 have established a medical review panel process. Fifteen states have a mandatory medical review process, whereas 3 states rely on a voluntary process. Thirty-five states have tort reform and have placed a cap on noneconomic damages. These caps range from $\$ 250,000$ to $\$ 2,350,000$, with the median cap of $\$ 465,900$. Only 8 states have placed a cap on total economic damages. These caps range from $\$ 500,000$ to $\$ 2,350,000$, with the median cap of $\$ 1,050,000$. All states have a filing fee for a medical malpractice lawsuit. These costs range from $\$ 37$ to $\$ 884$, with the median cost for filing of $\$ 335$.

CONCLUSIONS Medicolegal healthcare reform will continue to play a vital role in physicians' lives. It will dictate if physicians may practice proactively or be forced to act defensively. With medicolegal reform varying greatly among states, it will ultimately dictate if physicians move into or away from certain states and thus guide the availability of healthcare services. A desirable legal system for neurosurgeons, including caps on economic and noneconomic damages and availability of medical review panels, can lead to safer practice.

https://thejns.org/doi/abs/10.3171/2020.8.FOCUS20616

KEYWORDS medicolegal; medical review panel; tort reform; neurosurgery

$\mathrm{T}$ HERE are approximately 85,000 lawsuits filed against medical practitioners every year in the US. ${ }^{1}$ Among these lawsuits, neurosurgery has been identified as a "high-risk specialty" with an exceptional chance of any given neurosurgeon having medical malpractice suits filed against them. ${ }^{2,3}$ Although data from the National Practitioner's Data Bank show that there has been a steady downward trend in medical malpractice payments since $2000,{ }^{4}$ medical liability and fear of malpractice claims have led to many negative sequelae for practitioners in the American medical system. These include the practice of defensive medicine, fear of call coverage, and ultimately burnout and career changes. Major issues affecting the overall medicolegal environment include tort reform, the formation of medical review panels, the increasing practice of defensive medicine, and the rising costs of medical malpractice insurance. In this study, we provide a concise update of the current medicolegal environments of the 50 states and provide a general guide to favorable and unfavorable states in which to practice neurosurgery.

\section{Methods}

Data were acquired related to state-by-state medical review panel status, noneconomic damage caps, econom- 
ic damage caps, and civil suit filing fees. Information was retrieved through state medical board websites as well as a Google search of "medical legal reform mechanisms, 'Name of State'." Data were taken from .gov websites when possible to ensure the most up-to-date information in a realm of law that is rapidly evolving. States were placed into 5 categories based on the status of their current medical legal environment. These categories were Excellent, Very Good, Good, Fair, and Poor. "Excellent" is defined as a state that has the presence of a medical review panel and a cap on both noneconomic and economic damages. "Very Good" is defined as a state that has the presence of a medical review panel and a cap on noneconomic damages. "Good" is defined as a state that either has the presence of a medical review panel but the absence of caps on noneconomic and economic damages or the absence of a medical review panel with caps on both noneconomic and economic damages. "Fair" is defined as a state that has the absence of a medical review panel and the presence of a cap on noneconomic damages. "Poor" is defined as a state that has the absence of a medical review panel as well as the absence of caps on noneconomic or economic damages. Because the cost of filing a medical malpractice lawsuit may be a deterrent, these data were collected and used to rank states who otherwise have comparable data in the other categories. For comparisons between groups, one-way ANOVA with a Tukey post hoc test was used, and results were considered significant if $\mathrm{p}<0.05$.

\section{Results}

Of the 50 states in the US, 18 have established a medical review panel process. Fifteen states have a mandatory medical review process, whereas 3 rely on a voluntary process. Thirty-five states have tort reform and have placed a cap on noneconomic damages. These caps range from $\$ 250,000$ to $\$ 2,350,000$ with the median cap of $\$ 465,900$. Only 8 states have placed a cap on total economic damages. These caps range from $\$ 500,000$ to $\$ 2,350,000$ with the median cap of $\$ 1,050,000$. All states have a filing fee for a medical malpractice lawsuit. These costs range from $\$ 37$ to $\$ 884$ with the median cost for filing of $\$ 335$.

Below we provide a detailed, alphabetical list of individual state statutes and relevant updates. For a more easily comparable list of all states ranked from best to worst for medicolegal environment, see Table 1. In addition, Fig. 1 shows a map depicting each of the states categorized according to their current medicolegal status.

\section{Alabama}

The state of Alabama currently does not have a medical review panel process. There is a cap on noneconomic damages, which was set in 2018 in accordance with Alabama Code Title 6, Civil Practice $\S 6-5-544$, at $\$ 400,000$. There is no limit on economic damages.

\section{Alaska}

The state of Alaska currently has a mandatory medical review panel process if the two parties are unable to arbitrate. There is a cap on noneconomic damages set at $\$ 250,000$; however, the cap is raised to $\$ 400,000$ for cases that involve severe impairment resulting in higher than $70 \%$ disability or wrongful death. There is no limit on economic damages.

\section{Arizona}

The state of Arizona currently has no medical review panel process. There is no limit on noneconomic or economic damages. The Arizona Constitution states that no law shall be enacted limiting the amount of damages to be recovered for causing death or injury to a person.

\section{Arkansas}

The state of Arkansas currently has no medical review panel process. There is no limit on noneconomic or economic damages. In 2018, a suggested cap of $\$ 500,000$ on noneconomic damages was voted down.

\section{California}

The state of California currently has no medical review panel process. There is a cap on noneconomic damages of $\$ 250,000$. The cap on noneconomic damages was set in 1975 and has remained unchanged. There is no limit on economic damages.

\section{Colorado}

The state of Colorado currently has no medical review panel process. There is a cap on noneconomic damages set at $\$ 300,000$. Additionally, there is a cap on economic damages set at $\$ 1,000,000$.

\section{Connecticut}

The state of Connecticut currently has no medical review panel process. There is no cap set on noneconomic or economic damages.

\section{Delaware}

The state of Delaware currently has a mandatory medical review panel process. It does not have a cap for noneconomic or economic damages.

\section{Florida}

The state of Florida currently has no medical review panel process. There is a cap on noneconomic damages set at $\$ 500,000$. This cap is raised to $\$ 1,000,000$ for wrongful death. The cap on noneconomic damages was set in 2003, deemed unconstitutional by the Florida Supreme Court in 2017, and reinstated by the Florida House Civil Justice Committee in 2019. There is no cap set on economic damages.

\section{Georgia}

The state of Georgia currently has no medical review panel process. There is a cap on noneconomic damages set at $\$ 350,000$. The noneconomic damages cap is raised to $\$ 700,000$ if more than one facility is liable. A total cap is set at $\$ 1,050,000$, which includes all economic and noneconomic damages. 
TABLE 1. Summary of the current medicolegal reforms in the US

\begin{tabular}{|c|c|c|c|c|c|}
\hline $\begin{array}{l}\text { Category } \\
\text { \& State }\end{array}$ & $\begin{array}{c}\text { Medical } \\
\text { Review Panel }\end{array}$ & $\begin{array}{c}\text { Economic } \\
\text { Damages Cap }\end{array}$ & $\begin{array}{l}\text { Noneconomic } \\
\text { Damages Cap }\end{array}$ & $\begin{array}{l}\text { Civil Suit } \\
\text { Filing Fee }\end{array}$ & $\begin{array}{l}\text { Approx Cost of Medical } \\
\text { Malpractice Ins }{ }^{*}\end{array}$ \\
\hline \multicolumn{6}{|l|}{ Excellent } \\
\hline Louisiana & Yes & $\$ 500,000$ & $\$ 500,000$ & $\$ 201$ & $\$ 53,021$ \\
\hline New Mexico & Yes & $\$ 600,000 \dagger$ & $\$ 600,000 \dagger$ & $\$ 132$ & $\$ 74,900$ \\
\hline Indiana & Yes & $\$ 1,800,000$ & Providers liable for first $\$ 500,000$ & $\$ 157$ & $\$ 59,214$ \\
\hline Nebraska & Yes & $\$ 2,250,000 \dagger$ & $\$ 2,250,000 \dagger$ & $\$ 335$ & $\$ 20,720$ \\
\hline Virginia & Yes; voluntary & $\$ 2,350,000 \dagger$ & $\$ 2,350,000 \dagger$ & $\begin{array}{c}\text { Varies by county \& } \\
\text { case type }\end{array}$ & $\$ 65,791$ \\
\hline Alaska & Yes & Unlimited & $\begin{array}{l}\$ 250,000 ; \$ 400,000 \text { (>70\% dis- } \\
\text { ability or wrongful death) }\end{array}$ & $\$ 400$ & $\$ 54,188$ \\
\hline \multicolumn{6}{|l|}{ Very good } \\
\hline Montana & Yes & Unlimited & $\$ 250,000$ & $\$ 400$ & $\$ 82,125$ \\
\hline Kansas & Yes; voluntary & Unlimited & $\$ 325,000$ & $\$ 400$ & $\$ 35,807$ \\
\hline Idaho & Yes & Unlimited & $\$ 357,210$ & $\$ 221$ & $\$ 34,353$ \\
\hline Hawaii & Yes & Unlimited & $\$ 375,000$ & $\$ 315$ & $\$ 47,076$ \\
\hline Utah & Yes & Unlimited & $\$ 450,000$ & $\$ 400$ & $\$ 63,046$ \\
\hline Michigan & Yes & Unlimited & $\$ 465,900$ & $\$ 150$ & $\$ 64,680$ \\
\hline Maine & Yes & Unlimited & $\$ 500,000$ & $\$ 400$ & $\$ 50,077$ \\
\hline Massachusetts & Yes & Unlimited & $\$ 500,000$ & $\$ 195$ & $\$ 104,140$ \\
\hline Wisconsin & Yes & Unlimited & $\$ 750,000$ & $\$ 265$ & $\$ 24,950$ \\
\hline \multicolumn{6}{|l|}{ Good } \\
\hline Colorado & No & $\$ 1,000,000$ total damages & $\$ 300,000$ & $\$ 400$ & $\$ 47,075$ \\
\hline Georgia & No & $\$ 1,050,000$ total damages & $\$ 350,000 ; \$ 700,000$ (if >1 facility) & $\$ 400$ & $\$ 76,028$ \\
\hline New Hampshire & Yes; voluntary & Unlimited & Unlimited & $\$ 400$ & $\$ 78,683$ \\
\hline Delaware & Yes & Unlimited & Unlimited & $\$ 85$ & $\$ 92,219$ \\
\hline Wyoming & Yes & Unlimited & Unlimited & $\$ 70$ & $\$ 70,073$ \\
\hline \multicolumn{6}{|l|}{ Fair } \\
\hline South Carolina & No & $\$ 1,050,000 \dagger$ & $\$ 350,000$ & $\$ 165$ & $\$ 56,418$ \\
\hline lowa & No & Unlimited & $\$ 750,000$ & $\$ 400$ & $\$ 35,906$ \\
\hline Texas & No & Unlimited & $\$ 250,000$ & $\$ 400$ & $\$ 47,991$ \\
\hline California & No & Unlimited & $\$ 250,000$ & $\begin{array}{l}\$ 370(<\$ 25 \mathrm{~K} \text { cases }) \\
\$ 435 \text { (> } \$ 25 \mathrm{~K} \text { cases) }\end{array}$ & $\$ 42,482$ \\
\hline Ohio & No & Unlimited & $\$ 350,000$ & $\$ 37$ & $\$ 64,398$ \\
\hline Oklahoma & No & Unlimited & $\$ 350,000$ & $\$ 232.14$ & $\$ 49,883$ \\
\hline Nevada & No & Unlimited & $\$ 350,000$ & $\$ 400$ & $\$ 78,259$ \\
\hline Alabama & No & Unlimited & $\$ 400,000$ & $\$ 400$ & $\$ 41,737$ \\
\hline Missouri & No & Unlimited & $\begin{array}{l}\$ 450,000 ; \$ 700,000 \text { for } \\
\text { catastrophic injury }\end{array}$ & $\$ 400$ & $\$ 57,885$ \\
\hline North Dakota & No & Unlimited & $\$ 500,000$ & $\$ 95$ & $\$ 30,299$ \\
\hline North Carolina & No & Unlimited & $\$ 500,000$ & $\$ 150$ & $\$ 59,592$ \\
\hline West Virginia & No & Unlimited & $\$ 500,000$ & $\$ 200$ & $\$ 93,081$ \\
\hline South Dakota & No & Unlimited & $\$ 500,000$ & $\$ 400$ & $\$ 25,572$ \\
\hline Mississippi & No & Unlimited & $\$ 500,000$ & $\$ 400$ & $\$ 43,398$ \\
\hline Oregon & No & Unlimited & $\$ 500,000$ & Variesł & $\$ 50,131$ \\
\hline Florida & No & Unlimited & $\begin{array}{l}\$ 500,000 ; \$ 1,000,000 \\
\text { in wrongful death }\end{array}$ & $\$ 400$ & $\$ 124,139$ \\
\hline Tennessee & No & Unlimited & $\$ 750,000$ & $\$ 284.50$ & $\$ 40,980$ \\
\hline Maryland & No & Unlimited & $\$ 830,000$ & $\$ 185$ & $\$ 120,425$ \\
\hline
\end{tabular}


» CONTINUED FROM PAGE 3

TABLE 1. Summary of the current medicolegal reforms in the US

\begin{tabular}{|c|c|c|c|c|c|}
\hline $\begin{array}{l}\text { Category } \\
\text { \& State }\end{array}$ & $\begin{array}{c}\text { Medical } \\
\text { Review Panel }\end{array}$ & $\begin{array}{c}\text { Economic } \\
\text { Damages Cap }\end{array}$ & $\begin{array}{l}\text { Noneconomic } \\
\text { Damages Cap }\end{array}$ & $\begin{array}{l}\text { Civil Suit } \\
\text { Filing Fee }\end{array}$ & $\begin{array}{l}\text { Approx Cost of Medical } \\
\text { Malpractice Ins* }\end{array}$ \\
\hline \multicolumn{6}{|l|}{ Poor } \\
\hline Arizona & No & Unlimited & Unlimited & $\$ 73$ & $\$ 72,202$ \\
\hline Minnesota & No & Unlimited & Unlimited & $\$ 75$ & $\$ 23,266$ \\
\hline Washington & No & Unlimited & Unlimited & $\$ 110$ & $\$ 56,471$ \\
\hline Arkansas & No & Unlimited & Unlimited & $\$ 165$ & $\$ 40,674$ \\
\hline New York & No & Unlimited & Unlimited & $\$ 210$ & $\$ 128,006$ \\
\hline Illinois & No & Unlimited & Unlimited & $\$ 334$ & $\$ 100,645$ \\
\hline Connecticut & No & Unlimited & Unlimited & $\$ 360$ & $\$ 131,060$ \\
\hline Vermont & No & Unlimited & Unlimited & $\$ 400$ & $\$ 49,857$ \\
\hline Kentucky & No & Unlimited & Unlimited & $\$ 400$ & $\$ 62,272$ \\
\hline Pennsylvania & No & Unlimited & Unlimited & $\$ 400$ & $\$ 97,250$ \\
\hline New Jersey & No & Unlimited & Unlimited & $\$ 400$ & $\$ 99,615$ \\
\hline Rhode Island & No & Unlimited & Unlimited & $\$ 400$ & $\$ 125,805$ \\
\hline
\end{tabular}

Approx = approximate; Ins = insurance.

* Data on neurosurgery malpractice insurance rates were not immediately available. However, the field of obstetrics and gynecology (OBGYN) ranks similarly to neurosurgery in terms of high risk level and amount of malpractice payments awarded annually; ${ }^{3}$ thus, OBGYN malpractice rates for 2018 were listed for reference. ${ }^{16}$

† Combined cap for economic and noneconomic damages.

$\ddagger$ Oregon civil court fee: $\$ 172$ if < $\$ 10 \mathrm{~K} ; \$ 283$ for $\$ 10 \mathrm{~K}$ to $<\$ 50 \mathrm{~K} ; \$ 594$ for $\$ 50 \mathrm{~K}$ to $<\$ 1$ million; $\$ 884$ for $\$ 1$ million to $<\$ 10$ million; $\$ 1178$ for $\geq \$ 10$ million.

\section{Hawaii}

The state of Hawaii currently has a mandatory medical review panel process. There is a cap on noneconomic damages set at $\$ 375,000$. There is no cap set on economic damages.

\section{Idaho}

The state of Idaho currently has a mandatory medical review process. There is a cap on noneconomic damages set at $\$ 357,210$ as of 2019 (the cap on noneconomic damages is adjusted annually for inflation). There is no cap set on economic damages.

\section{Illinois}

The state of Illinois currently has no medical review panel process. The cap on noneconomic damages of $\$ 500,000$ per physician and $\$ 1,000,000$ per hospital was overturned in 2010 with Lebron v Gottlieb Memorial Hospital. There is now no cap on noneconomic or economic damages.

\section{Indiana}

The state of Indiana currently has a mandatory medical review panel process. Providers are liable for the first $\$ 500,000$ of noneconomic damages. There is a cap on economic damages set at $\$ 1,800,000$.

\section{lowa}

The state of Iowa currently has no medical review panel process. There is a cap on noneconomic damages set at $\$ 750,000$. This cap was raised from $\$ 250,000$ in February
2020. The cap on noneconomic damages does not apply in the case of wrongful death. There is no cap on economic damages.

\section{Kansas}

The state of Kansas currently has a voluntary medical review panel process. There is a cap on noneconomic damages set at $\$ 325,000$. This cap is set to be raised to $\$ 350,000$ on July 1,2022 . There is no cap on economic damages.

\section{Kentucky}

The state of Kentucky currently has no medical review process. Medical review panels were initiated in Kentucky in March 2017 and subsequently deemed unconstitutional by the Kentucky Supreme Court in October 2018. There is no cap set on noneconomic or economic damages.

\section{Louisiana}

The state of Louisiana currently has a mandatory medical review panel process. There is a cap on noneconomic damages set at $\$ 500,000$. Any amount of $\$ 100,000$ or more is covered via the Louisiana Patient's Compensation Fund, which acts as a secondary insurance. There is a cap on economic damages set at $\$ 500,000$.

\section{Maine}

The state of Maine currently has a mandatory medical review panel process. There is a cap on noneconomic damages set at $\$ 500,000$. There is no cap set on economic damages. 


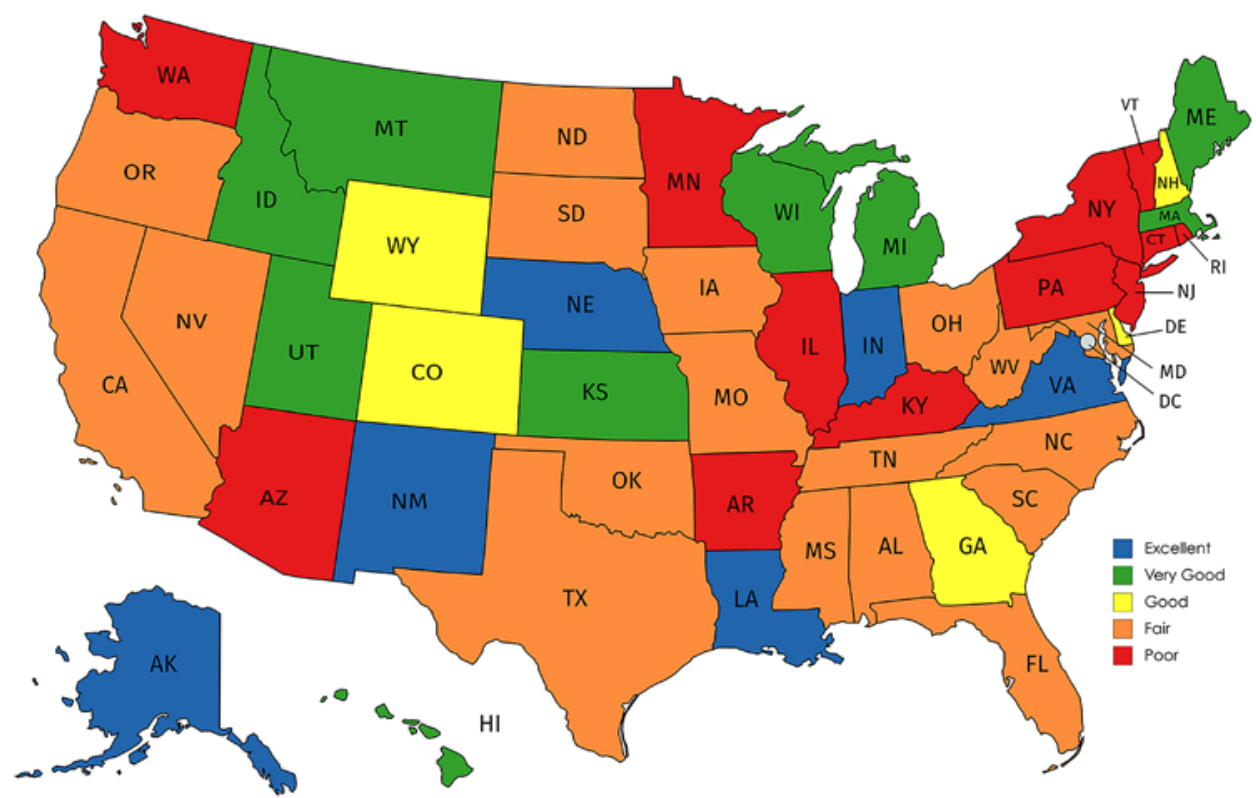

FIG. 1. Status of current medicolegal environment in the US. Color-coded geographical map of the US depicting the current medicolegal status category of each state as indicated by state color. Categories include Excellent (blue), Very Good (green), Good (yellow), Fair (orange), and Poor (red). Created using mapchart.net. CC BY-SA 4.0 (https://creativecommons.org/licenses/ by-sa/4.0/).

\section{Maryland}

The state of Maryland currently has no medical review panel process. There is a cap on noneconomic damages set at $\$ 830,000$. This cap is set to raise $\$ 15,000$ annually. There is no cap set on economic damages.

\section{Massachusetts}

The state of Massachusetts currently uses a medical review panel process. There is a cap set on noneconomic damages of $\$ 500,000$. There is no cap on economic damages.

\section{Michigan}

The state of Michigan currently uses a mandatory medical review panel process. The current cap on noneconomic damages was increased in 2019 from $\$ 280,000$ to $\$ 465,900$ to adjust for inflation. There is no cap on economic damages.

\section{Minnesota}

The state of Minnesota currently has no medical review panel process. There are no caps set on economic or noneconomic damages. However, any cases asking for more than $\$ 100,000$ require a special hearing.

\section{Mississippi}

The state of Mississippi currently has no medical review panel process. There is a cap on noneconomic damages set at $\$ 500,000$. There is no cap on economic damages.

\section{Missouri}

The state of Missouri currently has no medical review panel process. There is a cap on noneconomic damages of $\$ 450,000$ that is increased to $\$ 700,000$ in the event of catastrophic injury. There is no cap on economic damages.

\section{Montana}

The state of Montana currently uses a mandatory medical review panel process. There is a cap set on noneconomic damages at $\$ 250,000$. There is no cap on economic damages.

\section{Nebraska}

The state of Nebraska currently uses a mandatory medical review panel process. There is a cap on combined economic and noneconomic damages set at $\$ 2,250,000$.

\section{Nevada}

The state of Nevada currently has no medical review panel process. There is a cap set on noneconomic damages at $\$ 350,000$. There is no cap on economic damages.

\section{New Hampshire}

The state of New Hampshire currently uses a voluntary medical review panel process. There is no cap set on noneconomic or economic damages.

\section{New Jersey}

The state of New Jersey currently has no medical review panel process. There is no cap set on noneconomic or economic damages. 


\section{New Mexico}

The state of New Mexico currently uses a mandatory medical review panel process. There is a cap on total economic and noneconomic damages of $\$ 600,000$ and the healthcare provider's responsibility is capped at $\$ 200,000$.

\section{New York}

The state of New York currently has no medical review panel process. There is no cap set on noneconomic or economic damages.

\section{North Carolina}

The state of North Carolina currently has no medical review panel process. There is a cap on noneconomic damages set at $\$ 500,000$. There is no cap set on economic damages.

\section{North Dakota}

The state of North Dakota currently does not have a medical review panel process. There is a cap on noneconomic damages set at $\$ 500,000$. Although there is no formal economic damage cap, any economic damages award greater than $\$ 250,000$ may be challenged by the defendant and reviewed for reasonableness in the court. The defendant must persuade the court that the dollar amount does not reasonably reflect the injured patient's economic losses.

\section{Ohio}

The state of Ohio currently does not have a medical review panel process. It places a cap on noneconomic damages of $\$ 250,000$ or up to three times the plaintiff's perceived economic damages, with an overall maximum or $\$ 350,000$ per plaintiff or $\$ 500,000$ per case if there is more than one plaintiff.

\section{Oklahoma}

The state of Oklahoma currently does not have a medical review panel process. It caps noneconomic damages at $\$ 350,000$. There is no cap on economic damages.

\section{Oregon}

The state of Oregon currently does not have a medical review panel process. It caps noneconomic damages at $\$ 500,000$ per plaintiff or $\$ 1,000,000$ per case if the malpractice caused certain permanent and/or catastrophic injuries.

\section{Pennsylvania}

The state of Pennsylvania currently does not have a medical review panel process. It does not cap economic or noneconomic damages.

\section{Rhode Island}

The state of Rhode Island currently does not have a medical review panel process. It does not cap economic or noneconomic damages.

\section{South Carolina}

The state of South Carolina currently has no medical review panel. There is a cap on noneconomic damages of $\$ 350,000$. The total damages, including noneconomic and economic, cannot exceed $\$ 1,050,000$.

\section{South Dakota}

The state of South Dakota currently has no medical review panel process. It caps noneconomic damages at $\$ 500,000$. There is no cap on economic damages.

\section{Tennessee}

The state of Tennessee currently has no medical review panel process. It caps noneconomic damages at $\$ 750,000$. This cap may be extended to $\$ 1,000,000$ for death or catastrophic damage. There is no cap on economic damages.

\section{Texas}

The state of Texas currently does not have a medical review panel process. It caps noneconomic damages to $\$ 250,000$, with the provision to extend this to $\$ 500,000$ if spanning two institutions with neither institution paying more than $\$ 250,000$. There is no cap on economic damages.

\section{Utah}

The state of Utah currently uses a medical review panel process. It caps noneconomic damages at $\$ 450,000$ but does not cap economic damages.

\section{Vermont}

The state of Vermont does not have a medical review panel process. It does not cap economic or noneconomic damages.

\section{Virginia}

The state of Virginia currently has a voluntary medical review panel process. It caps total economic and noneconomic damages at $\$ 2,350,000$ overall. This cap is increased by $\$ 50,000$ each year for inflation.

\section{Washington}

The state of Washington does not have a medical review panel process. It does not cap economic or noneconomic damages.

\section{West Virginia}

The state of West Virginia currently has no medical review panel process. It has a noneconomic damage cap of $\$ 250,000$ for less severe injuries that is expanded to $\$ 500,000$ in the case of death or catastrophic injury. There is no cap on economic damages.

\section{Wisconsin}

The state of Wisconsin currently uses a mandatory medical review panel process. It places a cap on noneconomic damages of $\$ 750,000$ but has no cap on economic damages. 


\section{Wyoming}

The state of Wyoming currently has a mandatory medical review panel process. However, it places no cap on economic or noneconomic damages.

\section{Statistical Analyses}

To test whether malpractice cost is different between states categorized according to the status of their current medicolegal environment, statistical analyses were used to determine that there is no significant difference between the means of any pair of groups, including "excellent" versus "poor" $(p=0.27)$. This result implies that malpractice cost does not necessarily correlate with a better or worse medicolegal environment, and further reiterates the need to examine all factors independently when assessing the risks versus benefits of practicing in each state.

\section{Illustrative Case}

The need for a safe and standardized medicolegal environment cannot be overstated. To illustrate the importance of medicolegal reform, we present a lawsuit from the state of Florida.

In 2001, a neurosurgeon performed a craniotomy for resection of a benign mass causing obstruction of the ventricles. The patient was placed on an antiepileptic drug (AED) for postoperative seizure prophylaxis. On discharge home, despite prophylaxis, the patient had a postoperative seizure. The emergency medical technicians responded; however, they failed to secure the patient's airway and she subsequently developed a brain injury due to a lack of oxygen. Although three neurosurgeons had agreed that surgery should be performed, the patient's lawyers successfully argued that the surgery was unnecessary. Additionally, citing that the fact that the neurosurgeon not checking AED levels prior to discharge was the root cause of her injury, a jury awarded the patient $\$ 16$ million as compensation. ${ }^{5}$

Several key facts should be highlighted in this case. First, this case occurred prior to tort reform in Florida. In 2003, Florida was successful in setting a cap on noneconomic damages at $\$ 500,000$, which increased to $\$ 1,000,000$ in the case of wrongful death or permanent vegetative state. The Florida Supreme Court ultimately deemed this cap unconstitutional in 2017; however, the Florida House Civil Justice Committee subsequently reinstated the cap in 2019.,7 Also, a recent Cochrane review demonstrated no consistent evidence to suggest that preventative AED treatments are effective in reducing the number of seizures that occur postsurgery. ${ }^{8}$ From a neurosurgeon's perspective, this case highlights the fact that a case that any of us could be involved in might lead to what seems a harsh and perhaps unreasonable punishment.

\section{Discussion}

Healthcare reform in the US is an ever-evolving topic. Recently, tort reform and the legality of medical review panels have been the highlights of these discussions. Tort reform involves placing a cap on the amount of noneconomic damages, including pain and suffering, that may be awarded as a result of a medical malpractice suit. Medical review panels are pretrial assessments of the validity of a medical malpractice suit. These panels are used to decrease the burden of frivolous lawsuits on the courts. Kosty et al. ${ }^{9}$ showed the effectiveness of these panels in a review of the medical review process of Louisiana from 2008 to 2017. Louisiana has the highest number of malpractice suits filed per capita in the US at 44.1 per 100,000. Despite this high number of lawsuits, Louisiana ranks 40th for average payout at $\$ 28,465$. Furthermore, no neurosurgeon has had to go to trial in the 10 years of this study. This is due primarily to the removal of frivolous lawsuits and settling of valid lawsuits prior to trial. ${ }^{9}$

Neurosurgery has a high risk of malpractice claims due to the innate nature of the field. Many surgeries come with significant risk in an aging population with significant medical comorbidities. Elsamadicy et al. ${ }^{10}$ analyzed closed malpractice claims against neurosurgeons between 2003 and 2012, which illustrates this risk. They found that 2131 claims were filed against neurosurgeons within this time frame. Twenty-eight percent of these claims resulted in payment to the plaintiff, with the single largest payout being $\$ 5,600,000 . .^{10}$ Furthermore, Jena et al. showed that neurosurgeons have a $19.1 \%$ annual risk of facing a medical malpractice claim. ${ }^{3}$ Not surprisingly, frivolous lawsuits and increased premiums for insurance are the most common reasons cited by neurosurgeons for early retirement or restricting their practice to safer surgeries. ${ }^{11,12}$

The practice of defensive medicine as a deterrent for medical malpractice claims has been on the rise. The cost of this defensive medicine in the US is approximately $\$ 45-\$ 55.6$ billion annually. ${ }^{13,14}$ This astronomical cost is primarily due to the cost of diagnostic or therapeutic tests that often will not change the treatment algorithm the treating physician will use. Recently there has been a push for tort reforms throughout the US. Although this has helped to decrease the overall number of malpractice claims, it has not led to a significant change in the practicing of defensive medicine. ${ }^{15}$ Legislative change limiting liability is also often difficult to get enacted due to the sympathetic nature of significant legitimate malpractice cases and the power of the medical malpractice attorney lobbyists.

\section{Conclusions}

Medicolegal healthcare reform will continue to play a vital role in physicians' lives. It will dictate if physicians may practice proactively or continue to be forced to act defensively. With medicolegal reform varying greatly among states, the presence or absence of tort reform, medical review panels, and filing fees may be a significant factor in where a physician practices their trade. This is likely to be even more true for neurosurgeons given the intrinsically risky nature of our practice and the corresponding high medical malpractice insurance rates. This factor may contribute to whether a particular state has an abundance or shortage of neurosurgeons, leading to significant access consequences. A desirable legal system for neurosurgeons, including caps on economic and noneconomic damages and availability of medical review panels, can lead to safer practice. 


\section{References}

1. Galfand Berger. Philadelphia medical malpractice lawyers. Medical malpractice statistics. Accessed September 10, 2020. https://www.galfandberger.com/resources/medical-malpractice-statistics/

2. Studdert DM, Mello MM, Sage WM, et al. Defensive medicine among high-risk specialist physicians in a volatile malpractice environment. JAMA. 2005;293(21):2609-2617.

3. Jena AB, Seabury S, Lakdawalla D, Chandra A. Malpractice risk according to physician specialty. $N$ Engl J Med. 2011; 365(7):629-636.

4. Belk D. True cost of healthcare. Accessed September 10, 2020. https://truecostofhealthcare.org/malpractice_statistics/

5. Almeida W. Patient wins $\$ 16$ million malpractice lawsuit against med school. Miami Hurricane. February 2, 2007. Accessed September 10, 2020. https://www.themiamihurricane.com/2007/02/02/patient-wins-16-million-malpracticelawsuit-against-med-school/

6. Goguen D. Does Florida cap medical malpractice damages? Nolo.com. Accessed September 10, 2020. https://www.nolo. com/legal-encyclopedia/does-florida-cap-medical-malpractice-damages.html

7. Ash J. Bill would cap pain and suffering in med mal cases. The Florida Bar. March 18, 2019. Accessed September 10, 2020. https://www.floridabar.org/the-florida-bar-news/something/

8. Greenhalgh J, Weston J, Dundar Y, et al. Antiepileptic drugs as prophylaxis for postcraniotomy seizures. Cochrane Database Syst Rev. 2020;4(4):CD007286.

9. Kosty J, Jiang B, LeFever DC, et al. The medical review panel in Louisiana neurosurgery and beyond. Neurosurgery. 2019;85(6):E992-E1001.

10. Elsamadicy AA, Sergesketter AR, Frakes MD, Lad SP. Review of neurosurgery medical professional liability claims in the United States. Neurosurgery. 2018;83(5):997-1006.

11. Thomas R, Gupta R, Griessenauer CJ, et al. Medical malpractice in neurosurgery: a comprehensive analysis. World Neurosurg. 2018;110:e552-e559.

12. Rovit RL, Simon AS, Drew J, et al. Neurosurgical experience with malpractice litigation: an analysis of closed claims against neurosurgeons in New York State, 1999 through 2003. J Neurosurg. 2007;106(6):1108-1114.
13. Kachalia A, Mello MM. New directions in medical liability reform. N Engl J Med. 2011;364(16):1564-1572.

14. Mello MM, Chandra A, Gawande AA, Studdert DM. National costs of the medical liability system. Health Aff (Millwood). 2010;29(9):1569-1577.

15. Waxman DA, Greenberg MD, Ridgely MS, et al. The effect of malpractice reform on emergency department care. $N$ Engl J Med. 2014;371(16):1518-1525.

16. CunninghamGroup. Historic Medical Malpractice Insurance Rates. Accessed September 10, 2020. https://www.cunninghamgroupins.com/historic-medical-malpractice-insurancerates/

\section{Disclosures}

The authors report no conflict of interest concerning the materials or methods used in this study or the findings specified in this paper.

\section{Author Contributions}

Conception and design: LeFever, Menger, Kosty, Guthikonda. Acquisition of data: LeFever, Demand, Kandregula, Vega. Analysis and interpretation of data: LeFever, Demand, Kandregula, Vega, Trosclair. Drafting the article: LeFever, Demand, Kandregula, Vega, Hobley, Paterson. Critically revising the article: LeFever, Vega, Paterson, Trosclair. Reviewed submitted version of manuscript: LeFever, Trosclair. Approved the final version of the manuscript on behalf of all authors: LeFever. Statistical analysis: LeFever, Trosclair. Administrative/technical/ material support: LeFever, Trosclair. Study supervision: LeFever, Menger, Kosty, Guthikonda.

\section{Correspondence}

Devon LeFever: Louisiana State University Health Sciences Center, Shreveport, LA.dlefev@lsuhsc.edu. 